\title{
RESEARCH IN SPORT

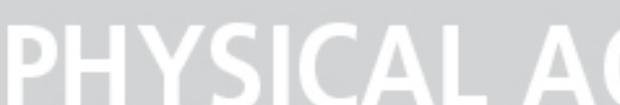

Adipokines levels in response todifferent intensity physical exercise protocols in young healthy men

Magalhães, Daniel Massote; Vaz, Lucas Neves; Rocha, Guilherme

Autor(es): $\quad$ Carvalho; Rocha, Natália Pessoa; Faria, Marcelo Henrique Salviano de;

Vieira, Erica Leandro Marciano; Nunes-Silva, Albená; Silva, Ana Cristina

Simões e

Publicado por: Imprensa da Universidade de Coimbra

URL

persistente:

URI:http://hdl.handle.net/10316.2/44141

DOI:

DOI:https://doi.org/10.14195/2182-7087_ex2018_78

Accessed : $\quad$ 26-Apr-2023 12:50:35

A navegação consulta e descarregamento dos títulos inseridos nas Bibliotecas Digitais UC Digitalis, UC Pombalina e UC Impactum, pressupõem a aceitação plena e sem reservas dos Termos e Condições de Uso destas Bibliotecas Digitais, disponíveis em https://digitalis.uc.pt/pt-pt/termos.

Conforme exposto nos referidos Termos e Condições de Uso, o descarregamento de títulos de acesso restrito requer uma licença válida de autorização devendo o utilizador aceder ao(s) documento(s) a partir de um endereço de IP da instituição detentora da supramencionada licença.

Ao utilizador é apenas permitido o descarregamento para uso pessoal, pelo que o emprego do(s) título(s) descarregado(s) para outro fim, designadamente comercial, carece de autorização do respetivo autor ou editor da obra.

Na medida em que todas as obras da UC Digitalis se encontram protegidas pelo Código do Direito de Autor e Direitos Conexos e demais legislação aplicável, toda a cópia, parcial ou total, deste documento, nos casos em que é legalmente admitida, deverá conter ou fazer-se acompanhar por este aviso. 


\section{ANNALS OF RESEARCH IN SPORT AND PHYSICAL ACTIVITY}




\section{ADIPOKINES LEVELS IN RESPONSE TODIFFERENT INTENSITY PHYSICAL EXERCISE PROTOCOLS IN YOUNG HEALTHY MEN}

Daniel Massote Magalhães'; Lucas Neves Vaz'; Guilherme Carvalho Rocha1; Natália Pessoa Rocha'; Marcelo Henrique Salviano de Faria'; Erica Leandro Marciano Vieira'; Albená Nunes-Silva²; Ana Cristina Simões e Silva ${ }^{1}$

KEYWORDS: Adipokines, Aerobic Exercise, Intensity.

\section{INTRODUCTION AND OBJECTIVE}

Adipose tissue is considered an endocrine organ that secretes bioactive peptides involved in autocrine, paracrineand endocrine functions, named as "adipokines"(1). There are three classical adipokines, adiponectin, leptin and resistin, which, respectively, exert anti-inflammatory actions, food intake control and pro-inflammatory effects ${ }^{2}$. Currently, the modulatory effects of physical exercise on adipokine levels have been recognized ${ }^{(2)}$, although there is scarce data comparing protocols of physical exercise with different intensity. Therefore, we assessed the acute effect of high and moderate intensity protocols of physical exercise on plasma and urine levels of adipokines.

\section{SUBJECTS AND METHODS}

Thirteen young healthy physically active men were recruited to four supervised training sessions. Two evaluation sessions were performed to measure body composition, physical activity, aerobic and anaerobic capacities before High-Intensity Interval Exercise (HIIE) and Moderate-Intensity Continuous Exercise (MICE) iso-work exercise sessions on a cycle

\footnotetext{
1 Federal University of Minas Gerais.

2 Federal University of Ouro Preto.

Email: danielmassote@yahoo.com.br; albenanunes@hotmail.com; acssilva@hotmail.com
} 
ergometer. The HIIE protocol included a 5-minute warm-up at $60-70 \%$ of heart rate peak (HRp) intensity followed by 10 sets of 30 seconds above $90 \%$ with 1 minute of recovery and 3 minutes of cool down (both at the same warm-up power). MICE protocol was performed at constant power corresponding at $60-70 \%$ of HRp and finalized at the same total work of HIIE. Blood and urine samples were collected before and after the exercise protocols, then stored at $-80^{\circ} \mathrm{C}$ for furtheranalysis of adipokine content (adiponectin, leptin and resistin) by enzyme-linked immunoassay (ELISA).

\section{RESULTS}

Plasma and levels of leptin,resistin and adiponectin did not differ in the comparison between baseline concentrations (before exercise protocols) and between levels after both exercise protocols. Urine concentrations of resistin and leptin also did not differ at baseline and after both exercise protocols. However, urine levels of adiponectin significantly increased after HIIE protocol ( $p=0,0005)$. In addition, the concentrations of adiponectin in urine were significantly higher following HIIE than after MICE $(p=0.0039)$.

\section{CONCLUSION}

Our study showed that the HIIE protocol induced a more intense increase in urine levels of adiponectin concentration in comparison to MICE. This result suggests that HIIE may be an interesting training intervention in order to improve metabolic profile.

\section{REFERENCE}

1. Ronti, T. Lupattelli, G. and Mannarino, E. (2006). The endocrine function of adipose tissue: an update. Clinical Endocrinology, 64, pp. 355-365.

2. A García-Hermoso, R J M. Ceballos-Ceballos, C E. Poblete-Aro, A C. Hackney, J. Mota, R. Ramírez-Vélez. (2016). Exercise, adipokines and pediatric obesity: a meta-analysis of randomized controlled trials. International Journal of Obesity (2005). 